\title{
Students' Perceptions Toward Anxiety Feelings When Speaking English
}

\author{
Windha Zulhernanda \\ Department of English Applied \\ Linguistics ( LTBI) \\ Universitas Negeri Medan \\ North Sumatera, Indonesia \\ windhazulhernanda@gmail.com
}

\author{
Busmin Gurning \\ Universitas Negeri Medan \\ North Sumatera, Medan
}

\author{
Sri Minda Murni \\ Univeristas Negeri Medan \\ North Sumatera, Indonesia
}

\begin{abstract}
This study investigated about students perceptions toward anxiety feelings when speak in english. The participant of this study were 3 students that studied in different class in private vocational high school in Sei Mencirim, Deli Serdang subdistrict. There were 2 female students and 1 male student. The technique of collecting the data by interview the students about their anxiety feelings when they speaking in English in their class. The data analysis have been analyzed by their perceptions from their statements by Rao, V.S.P Naraya P.S. and then analyzed based on the types of perception, such as Perceivers-Specific Characteristics, Target-Specific Characteristics, Situation-Specific Characteristics. The result of this study was The dominant types of the students perception was Situation-Specific Characteristics and The participants gain that perception greater than the social context that surrounds it, because such social influences can affect the behavior and thinking of the individual by stating that they will still feel worried when they want to speak in English because the English is a foreign language for them, so will still feel wrong in pronunciation, grammar, and vocabulary. because participants feel it from some of the conditions they experience based on what they feel, and they think.
\end{abstract}

Keywords - Students Perceptions; Anxiety; Speaking English

\section{INTRODUCTION}

Many of us have been in situations as language learners when we are asking questions and our minds mysteriously become empty. Or maybe our heads follow a teacher around the class when we are nervous waiting for our turn to speak, barely listening to the results of other students, our eyes are trained on the teacher seeing "unlucky victims" will be chosen to speak later. At other times we avoid the opportunity to communicate at all. While some students avoid talking because they are unprepared, uninterested, or unwilling to express themselves, most of the anxiety comes from feelings of alienation in the classroom, from lack of confidence, or because students fear communication itself and feel anxiety [1].

Task-based language teaching often utilizes incongruity and unpredictable learning activities to encourage communication. Arguably, tasks that are not focused in a sequence of activities that ends with controlled practice may unwittingly encourage anxiety. As Aida notes, many language teachers are concerned about the possibility that anxiety may function as an affective filter preventing learners from achieving a high level of proficiency in the language. Learners need to have attitudes and use strategies that encourage lowered anxiety, higher motivation, and confidence in their ability to convey what they want to say. One of the challenges for teachers is to provide the kind of classroom atmosphere that promotes lowanxiety.

Anxiety is related to self-focused, negative and anxious cognition during interaction. Highly anxious students often have relatively negative selfconcepts, underestimating the quality of their speaking ability when compared with others. While some may argue that a dose of anxiety is necessary to create a language learning "charge", for many students nervousness distracts from attending to and remembering new language, and will thus affect the practice required for language to be assimilated. An unwillingness to make an effort can be seen as debilitating in communicative language classrooms, where making an attempt to use new language forms is a central tenet of second language acquisition. This unwillingness may spark what Dayhof calls the "anxiety feedback loop" (p.27), in which anxiety is triggered by concern over being scrutinized and evaluated by others in a performance situation.

Anxiety disorders are characterized by a general feature of excessive fear (i.e. emotional response to perceived or real threat) and/or anxiety (i.e. worrying about a future threat) and can have negative behavioral and emotional consequences. Obsessive-compulsive and related disorders are characterized by obsessive, intrusive thoughts (e.g., constantly worrying about staying clean, or about one's body size) that trigger related, compulsive behaviors (e.g. repeated hand-washing, or excessive exercise). These behaviors are performed to alleviate the anxiety associated with the obsessive thoughts. Trauma- and stressor- related anxiety disorders are related to the experience of a trauma (e.g., unexpected death of a loved one, a car accident, or a violent incident) or stressor (e.g., divorce, beginning college, moving) [2].

The word "Perseptions" always uses in our daily activity. But, what is the actual meaning of perceptions? According to Sarwono [3] Perceptions is a someones' ability for organize some observation, the ability such as ability to distinguish, group and focus something that found. Because of that, someone people have the way different perceptions. It is 
possible because there are some distinguish in assessment system and the characteristic of their ownself.

Based on my observations, many students experience and feel anxiety until they feel panicked when they are told by their English teacher to speak in English. especially in schools of Al-Fajar Sei Mencirim Vocational School which is located at Jati Pasar IV Street, Gang Sekolah, Sei Mencirim District, Deli Serdang District. In the Al-Fajar Sei Mencirim Vocational School, there are 3 classes, namely X grade, XI grade, XII grade. in class XII consists of 11 boys and 10 girls. they have learned English from elementary school until now. Their speaking skills are expected to have started fluently and have confidence every time they want to speak English. but the fact is they still feel anxiety every time they want to speak in English. Therefore, the ressearcher is able to investigate the students' perceptions about their anxiety feelings when speak in English and able to know what their suggestions are about learning English so that they do not feel anxiety again.

The aim of this study were attemped to explain and describe students' perception towards their anxiety feelings when speak in english. to achieve this aim, the researcher have to formulate the research question such as :

1. How is the students' perceptions toward their anxiety feelings when speak in English?

2. What are the reasons when the students convey their perceptions about their anxiety feeling when speak in english?

\section{REVIEW OF LITERATURE}

\section{Anxiety Feelings}

Anxiety experienced in the course of learning a foreign language is specific and unique [4] [5]. It is a complex, multidimensional phenomenon (Young, 1991b). Students in language classes may engage in negative selftalk, ruminating over a poor performance, which affects their ability to process information in foreign language contexts [5].

anxiety is described as involving disturbing feelings of tension and anxiety by manipulating scientific equipment in a variety of daily life and academic situations. anxiety can also be described as a state of discomfort that occurs in responding to situations involving scientific tasks that are considered a threat to self-esteem. Such feelings have been shown to cause panic, tension, helplessness, fear, distress, shame, inability to cope, sweaty palms, restless stomach, difficulty breathing, and loss of ability to concentrate [6].

Previous research studies have shown that anxiety causes students in general withdraw from participation in the teaching and learning process. It has been suggested that solutions to anxiety problems and the resulting lack of participation can be found in teaching methodologies that move away from more traditional, teacher-centered classrooms and concentrate more on student-centered cooperative learning techniques [7]. It has been shown that cooperative learning techniques, when used to teach foreign languages, reduce anxiety levels in foreign language classes and increase the frequency of class participation. Noh [8] confirm Gregersen's findings. They investigated the effects of visual organization and cooperative learning on problem solving strategies in chemistry and they reported that cooperative learning methods reduce chemical class anxiety in students.

\section{Perception}

According to Nelson and Quick [9] "perception is the process of interpreting information about other people." From people's perceptions of menungging it is clear that all perceptions can depend on the information received. how you interpret information into correct information. in other words, even though the information received is the same, the way the person is interpreted is different based on the capacity of how to interpret it.

Rao and Narayan [10] define perceptions that are acceptable depending on one's behavior when conveying information that allows them to understand the situation around them, "perception is a process in which people choose, regulate, and interpret sensory stimuli to be meaningful. information about their work environment. "

This section is taken from a brief description of Nelson and Quick (op cit: 84-87) about three main characteristics that influence our perception of others:

- Perceivers-Specific Characteristics: The perception factor is familiarity with the object of perception. when between informants and observers have good closeness, it is better to make observations to make good decisions about certain situations. but you must see the informant very accurately, and must produce very accurate data during observation.

- Target-Specific Characteristics: This perception is strongly influenced by social perception. the physical appearance of an informant is very influential such as night, estimated age, and also gender. the most important is the physical appearance and feelings received by observers.

- Situation-Specific Characteristics: This is a very significant factor that influences the impression that is formed about a person by an individual. In other words, the social context of interaction is the main influence. Situational signal strength often gives clear indications of behavior that can be accepted in a particular environmental context. Thus, there are particulars that affect individual behavior, which does not always affect the individual's disposition. This is what is called the principle of discounting in social perception.

\section{RELATED STUDY}

Daly focuses much on communication apprehension and cites genetic disposition; early reinforcements and punishments; early communication skills; and exposure to appropriate model of communication as the possible factors for language anxiety [1] .

Participants in Von Wörde's study report that noncomprehension, the pace and the risk of being singled out in speaking activities, the limited time devoted to pedagogical and instructional practices, the risk of being humiliated 
through error correction and the presence of native speakers could make them more anxious than usual [11].

Gregersen and Horwitz suggest that perfectionism might impede high anxious learners' performance and some recommendations are offered to cope with perfectionist tendencies [12].

Woodrow draws a distinction between in-class and outof-class anxiety and finds that communication with teachers and performing in front of a class are the major contributors to language anxiety in speaking classes[13]. Specifically, giving oral presentations, role-play in front of class, contribution to formal discussions, answering teacher questions, informally speaking teachers were reported as major reasons for learners' in-class anxiety.

Moreover, Tanveer's 2007 study reveals that it is the intrinsic motivators, the learner's self in particular, that usually result in anxiety-breeding situations.

\section{RESEARCH Methodology}

Subject

At Al-Fajar Vocational High Scool in Sei Mencirim Subdistrict, the researcher investigate the students' perceptions towards anxiety feeling when speak in English. the participants were 3 students who is in XII grade. There are 2 girls and 1 boy.

\section{Techniques of collecting the data}

Fontana and Frey pointed out that "asking questions and getting answers is a much harder task than it may seem at first" (p. 645). However, interviews play a role in qualitative data collection procedures because they help the researcher get an indepth understanding of participants in a study.

The data have been taken from interview those students about all of things of their anxiety feelings when speak in English. the questions were :

1. What are your feelings when told by your English teacher to speak in English?

2. Why do you feel anxious when you speak English ?

3. What do you do to you to reduce your anxiety?

4. According to your perspective, what your English teacher has to do with you is that you don't feel anxious anymore ?

5. What are your suggestions for people who experience the same things as you when you want to speak in English?

\section{Techniques of analysis the data}

After the researcher ask the question to the participants, the researcher analyzed their perception from their statement about their anxiety feelings and the solution for other people when they want to speak in English by based on the types of perception, such as Perceivers-Specific Characteristics, Target-Specific Characteristics, Situation-Specific Characteristics. And then next to poerception process by Rao input quality will determine the output. inputs such as information, object, people, event, and etc. will be processed by means of selection and interpretation and will produce output such as behavior, action, attitude, belief, and feeling.
Variables in the perceptual process:

Inputs : all events that can be from people and events received by perceiver.

Process : all results received from the perceiver, will be processed through selection and interpretation.

Outputs : results that can be after the selection process and interpretation of it

Behavior :any behavior, action, attitude, belief, and feeling from someone who will produce a new set of persception

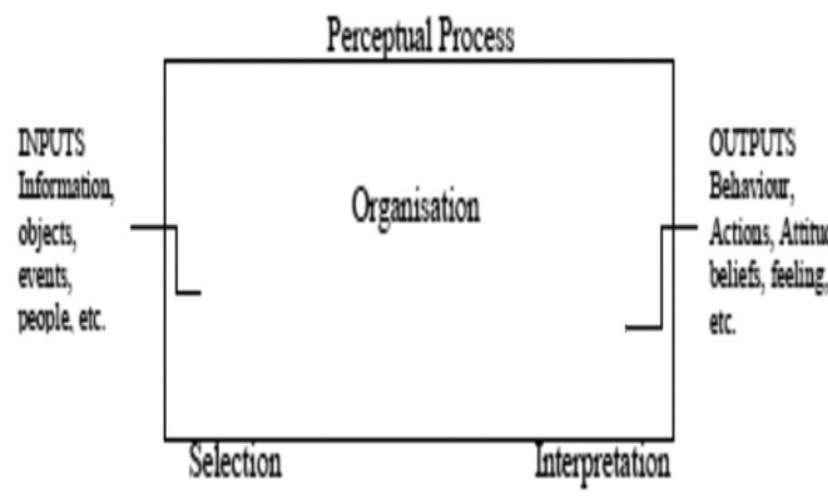

Fig 1. The Perceptual Process from Rao, V.S.P. And Narayana, P.S.

\section{RESUlt AND Discussion}

After interview the participant, the researcher found that :

Researcher : What are your feelings when told by your English teacher to speak in English?

Translate to English :

Student A : every time I am told by my English teacher to speak in English, I always feel anxious, and nervous. Sometimes my mind is blank, doesn't know what to say, until I stammer when talking.

Student B : if I am told to speak in English, I also feel anxious and afraid, if the pronouncation I say is incorrect, or the grammar is wrong.

Student C : if I also feel anxious, sometimes I feel nervous until my body sweats. I don't know what I want to say, just blank my mind.

Researcher : Why do you feel anxious when you speak English?

Translate to English :

Student A : I feel anxious, because I can't pronounce every English word correctly, and suddenly the word I want to say all spontaneously forgets in my brain.

Student C : yes I am like that too, I feel anxious because I don't understand at all what I want to say, I only know a few words in English that are often said

Student B : yes I also feel anxious, because my English speaking ability is very bad. I understand what people say in English, but I can't say it at all. Immediately blank my mind. 
Researcher : What do you do to you to reduce your anxiety ?

Translate to English :

Student C : I tried to calm my mind, and said to myself "if you can, you can do it!"

Student A : I will try it even though it takes a long time to talk because I thought about what would be said in the next sentence.

Student B : I will try to continue to speak in English. The problem is right or wrong later, the important thing is people understand, even though I am actually afraid to try.

Researcher : According to your perspective, what your English teacher has to do with you is that you don't feel anxious anymore?

Translate to English :

Student A : what our English teacher is doing is good. She always said "let's just talk, no need to be afraid, bro or right problem later, what's important to try"

Student C : yes. Therefore we are always motivated to speak English. She always said also "don't be afraid, let's talk, try. All already use English. Examples of smartphones and laptops. You can understand the language of smartphones and laptops that you see every day, but you can't say them "

Researcher : What are your suggestions for people who experience the same things as you when you want to speak in English?

Translate to English :

Student B : everyone must be afraid to speak in English, everyone would feel their mind Blank. But it continues to be tried right or wrong matters later.

Student C : the same as me, say to yourself if you can, nothing is impossible, everyone can. Although all of them need time to calm down from anxiety. And it takes time to learn to speak in English

From the results of interviewing the students above, the researcher can conclude that what makes them feel anxious when they speak English is:

\section{Anxious of grammar said wrong}

2. anxious of the pronouncation being said incorrectly

3. Blank mind when speaking in English. Do not know what words you want to say, because you only know the vocabulary that is often heard so that it ends up stumbling when talking

It is one case that make the students feel complicated and feel anxious when speaking in English, and this also makes the ability to speak english not increase.

So, the output that contains about behavior, attitude, action, and belief and feeling the students. From behavior, students feel nervous every time they speak English and make their minds blank, because they always feel anxious, if grammar and pronouncement that said was wrong. Finally, many bad words to mention.

So, attitude when they want to speak English, always remember the motivations given by their English teacher to them. And their action is they also motivate themselves to be able to speak English by saying in their hearts that they can do it. And they always believe that motivating themselves will make them able to reduce their anxiety and make them able to convince themselves that they can speak English. So, based on the data analysis, the dominant types of Percerption is Situation- Specific Characteristic beacause the social context of interaction is the main influence

\section{CONCLUSION}

Although many of us have been in situations as language learners when we are asking questions and our minds mysteriously become empty. At other times we avoid the opportunity to communicate at all. While some students avoid talking because they are unprepared and always feel anxious.

Based on the data analysis, it has been found difficult for students about their anxiety feelings when speaking in English. students feel nervous every time they speak English and make their minds blank, because they always feel anxious, if grammar and pronouncement that said was wrong. Finally, many bad words to mention. But they always motivate themselves to be able to speak English by saying in their hearts that they can do it. And they always believe their self-motivation will make them able to reduce their anxiety and make them able to convince themselves that they can speak English.

Implication for education :

1. There is need more motivation for the students' self in order they are sure that they can definitely speak English.

2. Need more training for speaking English.

\section{REFERENCES}

[1] Daly, J.A. (1991). Understanding communication apprehension: Anintroduction for language educators. In E.K. Horwitz \& D. J. Young (Eds.), Language Anxiety: From theory and research to classroom implications (pp. 3-13).

[2] Martin JL, Sainz-Pardo M, Furukawa TA, Martín-Sánchez E, Seoane T, Galán C (September 2007). "Benzodiazepines in generalized anxiety disorder: heterogeneity of outcomes based on a systematic review and meta-analysis of clinical trials". Journal of Psychopharmacology. 21 (7): 774-82.

[3] Sarwono, S.W. (1983). Pengantar Umum Psikologi. Jakarta: Bulan Bintang

[4] Horwitz, E.K., Horwitz, M., Cope, J., 1986. Foreign language classroom anxiety. The Modern Language Journal 1, 125-132.

[5] MacIntyre, P.D., Gardner, R.C., 1989. Anxiety and second-language learning: Toward a theoretical clarification. Language Learning 39, 251-275.

[6] Seligman Walkman, M.E.P., Walker, E.F., \& Rossenhan, D.L. (2001). Abnormal Psychology (4thedition). N.Y.:W.W. Norton \& company, Inc. 
[7] Gregersen,Tammy(1999). Improving the interaction of communicatively anxious students using Cooperative learning. Lenguas Mordernas.

[8] Noh Taehee, Yeo Kyeonghee, Jeon, Kyungwoon, Kim, Changmin, \& Choong, Hee (2000). The effects of visual organization and cooperative learning in problem-solving strategy. Journal of the Korean Association of Research in Science Education, 20(4), 519-526.

[9] Quick, D.L. and Nelson, J.C. (1997), Organisational Behavior: Foundations, Realities, and Challenges, (New York: West Publishing Company), pp. 83-84.

[10] Rao, V. S. P. And Narayana, P. S. (1998), Organisation Theory and Behaviour, (Delhi: Konark Publishing Company), (329-330)
[11]Von Wörde, R. (1998). An investigation of students' perspectives on foreign language anxiety. Unpublished Ph. D. Dissertation, George Mason University, Washington D.C.

[12]Gregersen, T. S., \& Horwitz, E. K. (2002). Language learning and perfectionism: Anxious and non-anxious language learners' reactions to their own oral performance. The Modern Language Journal, 86(4), 562570 .

[13]Woodrow, L. (2006). Anxiety and speaking English as a second language. $R E L C, 37(3), 308-328$ 